The Historical Journal

http://journals.cambridge.org/HIS

Additional services for The Historical Journal:

Email alerts: $\underline{\text { Click here }}$

Subscriptions: Click here

Commercial reprints: Click here

Terms of use : $\underline{\text { Click here }}$

\title{
POLITICAL UNION WITHOUT SOCIAL REVOLUTION: VINCENZO GIOBERTI'S PRIMATO
}

BRUCE HADDOCK

The Historical Journal / Volume 41 / Issue 03 / September 1998, pp 705 - 723

DOI: null, Published online: 08 September 2000

Link to this article: http://journals.cambridge.org/abstract S0018246X98007961

How to cite this article:

BRUCE HADDOCK (1998). POLITICAL UNION WITHOUT SOCIAL REVOLUTION: VINCENZO GIOBERTI'S PRIMATO. The Historical Journal, 41, pp 705-723

Request Permissions : $\underline{\text { Click here }}$ 


\title{
POLITICAL UNION WITHOUT SOGIAL REVOLUTION: VINGENZO GIOBERTI'S PRIMATO
}

\author{
BRUGE HADDOCK \\ University of Wales, Swansea
}

\begin{abstract}
A B S T R A CT. Vincenzo Gioberti's Del primato morale e civile degli italiani (I843) has been acknowledged as a major influence on moderate liberal thinking in the Risorgimento. Yet historians and political theorists have tended to dismiss the text as ponderous, unreadable or worse. The concern of this paper is to present what was once seen as a canonical text in terms that might make its initial appeal intelligible. Gioberti's text is set in the context of theological reappraisals within the Catholic tradition sparked by the rise of the national idea. The Primato managed to bring together currents of thought which are often regarded as antithetical. Catholic universalism was used to buttress and legitimize a specific view of the Italian nation. Gioberti's synthesis was to have a lasting impact on Italian liberalism, fostering a regard for established traditions rather than abstract rights. It also served to isolate revolutionaries and reactionaries in a dramatic and decisive decade for political debate in Italy.
\end{abstract}

I

Vincenzo Gioberti's Del primato morale e civile degli italiani, published in two volumes in Brussels in I 843, enjoys the dubious distinction of instant acclaim from contemporaries but ultimate neglect by historians of ideas and political theorists. ${ }^{1}$ Historians have continued to acknowledge the 'astonishing success' the text enjoyed, constituting as it did a focal point in the emergence of both moderate nationalist and neo-Guelph positions in the heady atmosphere of the I 840s. ' Yet the text itself is variously described as 'pedestrian', 'verbose', 'turgid', and even 'silly'. ${ }^{3}$ Nor has Gioberti's text fared much better in the recent revival of interest in federal theory in nineteenth-century Italy. His federalism is dismissed as an 'elegant expedient devised to resolve the grave problem of the co-existence of the papacy and the emerging nation state in Italy'. ${ }^{4}$ And the attempt to elaborate an argument which could reconcile the

\footnotetext{
${ }^{1}$ Vincenzo Gioberti, Del primato morale e civile degli italiani (2 vols., Brussels, I843); reference in what follows is to the second edition (2 vols., Capolago, I844).

${ }^{2}$ Christopher Duggan, A concise history of Italy (Cambridge, i 994), p. 7.

${ }^{3}$ Ibid., pp. 7, I I 2 ; Stuart Woolf, A history of Italy, I700-I860: the social constraints of political change (London, I979), p. 338; Derek Beales, The risorgimento and the unification of Italy (London, I $98 \mathrm{I}$ ), p. 58. The usual response, recently endorsed by Alfonso Scirocco, is simply to report that the book 'was read avidly, reviewed and discussed', despite being 'weighed down by occasionally annoying erudition'. See Alfonso Scirocco, L'Italia del risorgimento (Bologna, I990), p. 224.

${ }^{4}$ Gianfranco Miglio, cited in Gianfranco Morra, Breve storia del pensiero federalista (Milan, I993), p. 56.
} 
diverse views of nationalists, monarchists, and the church is described as a 'colossal equivocation' that was exposed in the neo-Guelph position as the I 848 revolutions unfolded, revealing Gioberti's much-vaunted 'realism' as anything but realistic. ${ }^{5}$

It is clearly the case that Gioberti's new readers are likely to come to the text with some trepidation. It may well be that a complete rehabilitation of the text is beyond the interpretative ingenuity of any commentator. From an historical point of view, however, it is important that what was once seen as a canonical text should be presented in terms that might (at least) make its initial appeal intelligible. In what follows I hope to make a case for a positive reading of a text which must clearly be approached from a number of different perspectives. In the process, light should be shed on the synthesis of Catholic doctrine and historical theorizing which was to continue to be a distinctive feature of Italian liberalism throughout the nineteenth century. ${ }^{6}$

The immediate political context of the Primato is relatively straightforward. The subversive activities of Mazzini's La Giovine Italia movement and other sects had given increasing cause for concern to the authorities in various parts of Italy throughout the I830s. What we begin to see in the I84os, however, is a hardening of view in moderate circles. Enlightened intellectuals and liberal aristocrats, sympathetic to the cause of reform, had begun to question the wisdom of Mazzini's insurrectionary strategy. Problems were perceived on two fronts. On the one hand, the despatch of small groups of insurgents to politically sensitive or vulnerable areas had so far proved to be ineffective. On the other hand, the sorts of doctrines preached by the Mazzinians gave no guarantee that concrete social, economic, and constitutional reforms would necessarily follow in the wake of their triumph. Reliance on the untrammelled will of the people in Mazzini's programme seemed to many moderates to be both naive and dangerous. ${ }^{7}$ The political lessons of $\mathrm{I} 793$ were still uppermost in their minds. The risk of a repetition of the reign of terror was simply not worth running, no matter how worthy the cause. And, in any case, the prospect of a political upheaval involving far-reaching social and economic changes would almost certainly precipitate a fierce and co-ordinated reaction.

An alternative strategy began to emerge in the i84os. Instead of looking to a movement motivated by pressure from below, a group of thinkers began to see

\footnotetext{
${ }^{5}$ Zeffiro Ciuffoletti, Federalismo e regionalismo: da Cattaneo alla lega (Bari, i994), p. 3I. For Gioberti's place in the federalist debate in the Risorgimento see Franco della Peruta, 'La federazione nel dibattito politico risorgimentale: I8 I 4-I847', in Ettore A. Albertoni and Massimo Ganci, eds., Federalismo, regionalismo, autonomismo: esperienze e proposte a confronto (2 vols., Palermo, I989), I, pp. 55-79.

${ }^{6}$ See Gabriele de Rosa, Il movimento cattolico in Italia: dalla restaurazione all'età giolittiana (Bari, I988), pp. I 7-44; Giovanni Spadolini, L'opposizione cattolica (Milan, I994), pp. 3-77; Guido de Ruggiero, The history of European liberalism, trans. R. G. Collingwood (Boston, I959), pp. 275-343; Richard Bellamy, Liberalism and modern society: an historical argument (Cambridge, I992), pp. 105-56; and Rosario Romeo, Il giudizio storico sul risorgimento (Palermo, I987).

7 The tone, in particular, of Mazzini's 'Istruzione generale per gli affratellati nella Giovine Italia' was viewed with alarm. See Edizione nazionale degli scritti di Giuseppe Mazzini, ed. L. Rava et al. (98 vols., Imola, I $906-40)$, II, pp. 45-56.
} 
more fruitful possibilities for political change in the conversion of one or more of the established ruling houses to the cause of reform. It would be misleading to see this group as a self-conscious school or party in the early I84os. By the later I 850 s, however, they would begin to dominate the national movement, at least in the north. As a group, they were deeply suspicious of populism in all its forms. Their interest in political reform was tempered always by a concern to maintain the social status quo. In the political sphere, too, their ambitions were strictly limited, extending (in most cases) no further than a modest constitutionalism. Yet even so moderate a stance had been interpreted as a revolutionary threat in the recent past. What made this group different was their links with the liberal aristocracy, particularly in Piedmont. They could wield influence without having to have recourse to subversive measures.

Vincenzo Gioberti ( $\left.180 \mathrm{I}_{-52}\right)$ was perhaps the most influential of the I840s moderates, though his links with the church made him a far from obvious political leader. A leading liberal Catholic, his tortuous career had involved him in uneasy relations with both ecclesiastical and political authorities. Though ordained in 1825 , his views were far from orthodox. In his youth, under the influence of Rousseau and Alfieri, he had adopted a fiercely antimonarchical position. His rejection of the identification of throne and altarthe centrepiece of restoration ideology - made him an object of suspicion in high circles. Despite appointments to the chair of theology at the University of Turin and as court chaplain in I83 I, he remained under a cloud. The Jesuits, in particular, against whom Gioberti would be embattled throughout his career, were openly critical of both his theology and politics. Gioberti felt obliged to resign his position at court. But he could not avoid further embroilment. In I 833 he was accused of being a member of a secret political society and of circulating copies of La Giovine Italia. Brief imprisonment was followed by a long period of self-imposed exile which ended only with the outbreak of revolutionary disturbances in 1848 .

Gioberti's position would shift markedly before he became the standardbearer of the moderates in the $1840{ }^{8}{ }^{8}$ In the early i $830 s$, however, he was close enough to Mazzini to lead people to suspect (wrongly) that he had actually been a member of La Giovine Italia. An open letter of 1834 addressed to the directorate of La Giovine Italia endorsed not only the political thrust but also the evangelical tone of the movement. Gioberti found no problem with the pantheism which has always disturbed Mazzini's orthodox Catholic followers. ${ }^{9}$ He could also accept Mazzini's historicist treatment of Christianity. The moral rather than political emphasis of the early Christian message is explained in terms of the needs of the times, with awareness of the equality of men before God serving as a necessary premise for the later establishment of civic equality. ${ }^{10}$ Nor does he baulk at the prospect of a realization of the 'reign of God on earth', inaugurated not through a second coming but by means of the

8 See A. Omodeo, Vincenzo Gioberti e la sua evoluzione politica (Turin, I94 I).

9 See Vincenzo Gioberti, 'Ai compilatori della Giovine Italia', in his Pagine scelte: edite ed inedite, ed. Pier Angelo Menzio (Turin, I922), p. 73.

10 See ibid., p. 75 . 
natural evolution of peoples, coming to live by God's law and embracing the implied principles of human association. ${ }^{11}$ What is perhaps even more surprising in Gioberti's specific position is his scathing dismissal of Pope Gregory XVI as a 'vile oppressor of peoples', sanctifying 'tyranny as a law', imposing 'slavery as a duty', condemning 'liberty as a crime'. ${ }^{12}$

Both the tone and content of the letter will come as a surprise to readers familiar with the more conciliatory and prudent style of the Primato. But certain basic commitments straddle both phases of Gioberti's thought. Most important of all was his contention that civilization could not but be built around religion. While in some formulations such a claim might have amounted to little more than a variation on the classic 'throne and altar' theme, the clear implication of Gioberti's argument was that the church itself should adapt to the spirit of the times. The doctrine of progress had become an article of civic faith in the nineteenth century; the church should embrace that faith and strive to make its own teaching a necessary point of reference for the political, social, and moral questions of the day. Gioberti was clearly expecting a good deal from the church. At times he sounds as if he would be content to see religion serve as a means towards secular goals, a position which the Jesuits had always resolutely opposed. What is certain is that adaptation on the scale Gioberti demanded would not be forthcoming during the pontificate of Gregory XVI. ${ }^{13}$

In the event, Gioberti would accommodate much of the church's traditional baggage long before the leaders of the church showed any real interest in reform or renewal. The transformation of his own views was prompted in the first instance by recognition of the futility of the Mazzinian insurrectionary strategy. The fiasco of the ${ }_{1} 84$ Savoy expedition, in particular, illustrated just how utopian Mazzini's assumptions had been. Ordinary people had little understanding of or interest in the arcane complexities of revolutionary intrigue. They could neither respond to nor initiate policy. And yet, as Mazzini himself recognized, without a groundswell of popular support, the efforts of revolutionary bands would be doomed to failure. ${ }^{14}$

If popular revolution could be discounted in the circumstances of the I 830 ,

11 See ibid., pp. 76, 84. 12 Ibid., p. 82.

13 Gioberti, of course, was not alone in his defence of a liberal Catholicism. Antonio Rosmini was similarly engaged in the fraught business of reconciling the universalist principles of the church with the contingent matter of the national question. No serious theologian could endorse the nationalist position without some modification. The national debate in the Risorgimento essentially invited a reappraisal of accepted notions of the relation between the spiritual and secular spheres. Rosmini, like Gioberti, found himself responding to arguments which traditional theologians might have preferred to ignore. In the political sphere, Rosmini elaborated a Catholic response to Hegel, focusing in particular on a theory of the state which would secure a universal spiritual role for the church. See Antonio Rosmini, La costituzione secondo la giustizia sociale con un appendice sull'unità d'Italia (Milan, I848); and Antonio Rosmini, Filosofia della politica (Milan, i837). Rosmini was also involved in tortuous negotiations for an Italian confederacy with the pope as honorary spiritual head. See Mario d'Addio, 'Rosmini e la confederazione italiana', Il politico, 69 (i 994), pp. I89-23i. For Gioberti's response to Rosmini's initiative see M. Menghini, Vincenzo Gioberti e la società per la confederazione italiana (Rome, I933).

14 See Giuseppe Mazzini, 'Manifesto della Giovine Italia', in Edizione nazionale, II, pp. 75-82. 
what alternative strategies offered tangibly better prospects? Gioberti was adamant that nothing would be achieved unless the established configuration of political powers in Italy were taken into account. And, despite his early republicanism and life-long contempt for the ethos of aristocracy and court, this could only mean that the national movement should seek a tactical rapprochement with the princes. ${ }^{15}$ In itself, this was little more than the statement of a problem. The divisions between the various Italian states had, after all, enabled foreign powers to exploit Italy for their own ends. Entrenched differences of interest and tradition would only be set aside if an alternative focus of allegiance could be devised. Italy as a symbol would clearly not suffice if in practice the separate states had to accept the dominance of one among them. What Gioberti sought was a genuinely Italian identity which transcended political divisions. He was to seek it in the church, at the time identified with the most obscurantist and arbitrary of the Italian states.

At the tactical level, Gioberti's break with Mazzini looks decisive. But profound differences of principle had also emerged. Gioberti, for example, was anxious to distance himself from Lamennais, whom Mazzini continued to regard as something of a mentor. In a letter of 20 December 1840 sent to the Gazette de France, Gioberti repudiated both republicanism and the idea of political equality, arguing that the fortunes of liberty and monarchy in Italy were inseparable. Not only did he deny the validity of Lamennais's identification of the emancipation of the people with the emancipation of the church from the state but he specifically linked the church as an institution with the Italian national cause. ${ }^{16}$

More significant, perhaps, is the theological gulf which now separated Gioberti from Mazzini. Gioberti rejected the evolutionary theory of knowledge which underpinned Mazzini's conception of progress. He now regarded the revealed wisdom of the Catholic tradition as an indispensable foundation for any understanding of the civil and natural worlds. Without an objective basis, knowledge would be reduced to psychological conviction. Indeed Gioberti specifically linked Descartes and Luther as the 'twin monsters of a false theology and a mendacious philosophy', opening the way to a riot of subjective interpretations in both religion and philosophy. ${ }^{17}$ Gioberti, instead, insisted that human knowledge had necessarily to be seen as an intuition of an external world; but, further, that the idea of an external world was itself inconceivable without recourse to a supernatural sphere. ${ }^{18}$ God served as a guarantor of the idea of reality, enabling human knowledge to be conceived as an attempt to grasp something concrete rather than simply as an interpretative portrayal of one of a myriad of possible worlds. In the political sphere, this meant that sensible discussion had necessarily to begin with the configuration of traditions

\footnotetext{
${ }^{15}$ See Woolf, A history of Italy, I700-I860, pp. $34^{\mathrm{I}-2 .}$

${ }^{16}$ See Pier Angelo Menzio's introduction to Gioberti, Pagine scelte, p. xxiv.

17 Vincenzo Gioberti, Introduzione allo studio della filosofia, ed. G. Calò (Milan, i939), II, p. 85.

18 See Vincenzo Gioberti, Teorica del sovranaturale o sia discorso sulle convenienze della religione rivelata con la mente umana e col progresso civile delle nazioni, ed. A. Cortese (Padova, I97o), II, pp. 3-10.
} 
and institutions that had developed historically, rather than with a utopian ideal conjured from philosophical imagination.

Gioberti was careful not to identify God with his creation. He avoided the pantheism of his earlier Mazzinian phase by means of a distinction between God as the absolute presupposition of an intelligible world and the actual world as the contingent product of God's omnipotence. Thus while it might be the case that human beings could not make sense of the world without invoking God, it did not follow that the world should be identified with God ontologically. ${ }^{19}$

It cannot be said that Gioberti's distinction had quite dispelled the suspicions of his orthodox critics. He had sought to elaborate a specifically Catholic philosophy based upon the idea of creation. But he did not embrace the style of theism associated with de Maistre and the Jesuits. In rejecting the Mazzinian (and Saint-Simonian) conception of progress, he had not thereby dissociated knowledge and human advancement. He insisted, however, that genuine progress could only emerge in a Catholic framework. Men could strive to improve themselves and their world; but in applying their minds to specific problems, they were actually participating in the infinite wisdom embodied in the created world. Human and divine reason were thus not different in kind, though the gulf between the two remained infinite.

Gioberti was clearly following a theologically precarious course. In attempting to reconcile the church with the scientific tradition, he ran the risk of antagonizing both reactionary and progressive opinion. His view of progress, in particular, involved him in difficulties which he was never to resolve satisfactorily. Though anxious to reassert the significance of a sound doctrinal foundation, which only the church could guarantee, he set no limit to the range of future possibilities. God in his infinite wisdom had created a world of infinite scope, enabling human beings to extend and develop themselves in limitless ways. In an important sense, God's wisdom was in fact revealed through men's endeavours. Thus while Gioberti might want to sustain an analytical distinction between divine and human wisdom, he nevertheless accepted that the historical emergence of communities was itself a manifestation of God's design. God's will was immanent in history; whether or not it should be identified with history is a vexed question which troubled his contemporaries and has continued to puzzle commentators to this day. ${ }^{20}$

But it is not as a theologian that Gioberti warrants our attention. He had never separated his activity as a theologian from his passionate commitment to the national movement. And it was Gioberti the political propagandist who was to capture the imagination of a generation. His shift in theological position in the 1830 s had been designed both to draw the church closer to liberal

19 See ibid., p. 5 .

20 For analysis of the implications of the immanentist position see Bertrando Spaventa, Opere, ed. Giovanni Gentile (3 vols., Florence, I 972), II, pp. 575-604. For a perceptive discussion of the bearing of Gioberti's theology upon his politics see Giampietro Berti, 'I moderati e il neoguelfismo', in Giovanni Cherubini et al., eds., Il movimento nazionale e il I848 (Milan, i 986), pp. 227-58, especially pp. $233^{-8 .}$ 
opinion and to allay the political fears of an educated bourgeoisie which had yet to flex its political muscles. The mobilization of the latter depended vitally on severing any lingering connection between the national movement and Jacobinism.

Revolution was still largely associated in the minds of educated Italians with social and economic chaos and political terror. Indeed the church itself had played a decisive role in converting the ideas of counter-revolutionary theorists into a conventional wisdom. ${ }^{21}$ Developments in Europe in the 1830 , however, especially in France, had considerably eroded the rigid ideological alliance which had been forged in I8I 5 . Catholic opinion, if not the church hierarchy, had been drawn into the reform movement. In Italy Manzoni, Pellico, and the contributors to Il Conciliatore and the Antologia had made distinctive Catholic contributions to a debate which had been dominated in the revolutionary period by the anti-clerical assumptions of the Enlightenment. What Gioberti supplied was the crucial political dimension, enabling views formed in the course of discussions of cultural and moral renewal, social, economic, and educational reform to coalesce in a common programme.

\section{I}

Gioberti became a national celebrity with the publication of Del primato morale $e$ civile degli italiani in $\mathrm{r} 843$. At a stroke he appeared to have isolated the Mazzinians and reassured the church and the established ruling families of Italy that all would not be lost in a properly founded Italian state. What he provided was a distinctive reading of Italian history which focused on the papacy as the quintessential national institution, the driving force behind the great achievements of the past and a promise that Italy could yet aspire to something rather more than the marginal role she had assumed in international affairs in modern times. A generation which had relished the literary ferment associated with Manzoni, Leopardi, and the wider romantic movement could look with renewed confidence on a political expression of Italian identity, secure in the knowledge that the right political choices could both restore the lustre of Italy's traditional institutions and make her once more a force to be reckoned with in Europe. It was an argument which quieted the fears of the politically timorous by treating recent Italian history as a deviation from the indigenous pattern of development, attributable largely to foreign (and especially French) influence. What was required in the circumstances which prevailed in the 1840 os was thus not new political adventures but a restoration of institutions and practices which had proved their worth in better times. Future progress depended crucially on a proper appreciation of the past.

Gioberti was at pains to root his argument in the familiar cultural experience of his countrymen. He had struck precisely the tone that might attract broad sections of the population to the national cause, avoiding the apocalyptic

${ }^{21}$ See, for example, Cesare Balbo, Sommario della storia d'Italia dalle origini fino ai nostri giorni, ed. L. G. Tenconi (Milan, I933), pp. 372-7. 
language of the more radical political sects while yet encouraging leaders to seek to release the latent potential of the nation by ridding Italy of foreign rule. It was a message which could not fail to appeal in general terms. What is surprising, however, is that it should inaugurate a new phase in the Risorgimento, encouraging even the most cautious and conservative liberals to endorse the national movement. ${ }^{22}$

Gioberti's success can be partly explained in terms of the modest nature of his political aims. He had been intent upon disturbing the status quo as little as possible, offering political proposals which might function as the lowest common denominator of support for an Italian state. His advocacy of a confederal solution to the Italian question should clearly be seen in these terms. Proposals which are bland in themselves, however, can assume a quite different dimension when viewed as the expression of a self-conscious movement. Gioberti's Primato had given the moderates a political identity.

Yet despite its instant appeal, the Primato remains a deeply ambiguous text. Gioberti's overriding concern had been to create a moderate consensus; and this involved him in omissions and emphases which puzzled his friends at the time and have continued to puzzle commentators anxious to place the work in the wider context of his developing ideas. In his anxiety not to antagonize either the church or the Piedmontese monarchy, he had felt obliged to temper earlier views. The Jesuits, for example, whom he had long held to be a major constraint upon any rapprochement between the church and progressive opinion, would find their civilizing role extolled. ${ }^{23}$ While the Piedmontese monarchy, notorious for its narrowly dynastic stance, would be lauded precisely for its identification with the Italian cause. ${ }^{24}$

Perhaps the most startling omission was the absence of any discussion of reform in the Papal States. Social and economic conditions had degenerated to such an extent during the pontificate of Gregory XVI that few could understand how a leading liberal could put his faith in a papacy which had studiedly ignored informed European opinion since r 83 I. Gioberti was himself aware of the dilemma but insisted that prospects for reform within the church and its territories would be maximized if the church could be persuaded to put itself at the head of the national movement. ${ }^{25}$ What Gioberti stresses time and again is the need to leave certain things unsaid in order to pursue his more immediate strategic objectives. Rather than confront the church's obvious political and administrative deficiencies directly, he chose to emphasize instead

\footnotetext{
22 See Cesare Balbo, 'Vita di Cesare Balbo scritta da lui medesimo', in ibid., p. I I. The immense cultural impact of Manzoni should not be ignored in this context. Though he does not figure as a political thinker of any standing, Manzoni had certainly accustomed educated Italians to think in terms of a cultural and religious identity that had been disclosed historically. See Natalino Sapegno, Ritratto di Manzoni e altri saggi (Bari, I992), pp. 45-62.

23 See Gioberti, Del primato morale e civile degli italiani, I, pp. 292-3.

24 See ibid., pp. I $9 \mathrm{I}^{-} 5$.

25 See Gioberti's letters to Mamiani dated i 8 Dec. I840 and 6 Apr. I84 I in Epistolario, ed. G. Gentile, G. Balsamo-Crivelli, and M. Menghini ( I I vols., Florence, I 927-37), III, pp. 99-i oo, I 8 I ; and the discussion in Giorgio Candeloro, Storia dell'Italia moderna (I I vols., Milan, i 956-86), II, pp. $360-7$ I.
} 
the positive advantages which would accrue to a church set once more at the centre of affairs. Similarly he hoped that his implicit criticism of the insular policies of the Piedmontese would be the more effective if he could focus on the potential impact upon the monarchy of a dominant national role. ${ }^{26}$

Gioberti's tactical dissimulation can easily mislead the unwary reader. But in his own mind his style of argument was at one with his principal goal. Political change in the I83os had foundered because active groups had based utopian ambitions on unrealistic foundations. The political world could not be made anew to fit the dreams of the pure in heart. One had necessarily to begin with the imperfect situation in which Italy found herself, building upon institutions which could lend political and moral weight to proposals that might otherwise get lost in a welter of good intentions. What an ideal Italian state might look like was simply not a politically relevant issue in the fluid circumstances of the I 840s. If Gioberti's text might be judged to be inconclusive or evasive from a theoretical point of view, it should at least be seen as a fitting political representation of the tactical realism he was so anxious to encourage.

It was Gioberti's elevation of realism to the status of an article of faith that enabled moderates who might not share his view of the special role of the Catholic church to identify with his position. He insists that 'no regime ... can easily establish itself, or, however established, can last, if it does not fit together with and adapt itself to the special conditions of the nation to which it is applied'. ${ }^{27}$ The point to stress is that, unlike in Mazzini's treatment, the nation, as a 'natural' product of history, precedes the imposition of narrowly political arrangements. The state, as a work of artifice, can be well or ill made. And the wise statesman ignores at his peril the 'natural' materials at his disposal. Precipitate haste, for example, attempting 'to destroy with violence' the unique conditions which distinguish a particular nation, is a recipe for disaster, an undertaking 'for the most part impossible, and always horrible, execrable and calamitous'. ${ }^{28}$ Even Napoleon, acknowledged to be the political genius of the age, had foundered because he had sought 'to refashion the political world in a moment; but his edifice exploded and vanished in an instant like a meteor'. ${ }^{29}$ The political lesson was clear. Lasting political change could only be achieved within the tried channels of an established culture.

The central role which awaited the church in Gioberti's scheme of things was essentially a consequence of its place in the development of Italian culture. Church and state had been so intertwined since Roman imperial days that 'the desire to distinguish the interests and rights' of the one from the other was to countenance an operation 'repugnant to the nature of things'. ${ }^{30}$ Indeed the church hierarchy had penetrated every aspect of the institutional life of the nation, leaving the nation only a residual identity outside the church. To strive for a national Risorgimento outside and against the interests of the church

\footnotetext{
26 See Gioberti's letter to Mamiani dated I 3 Aug. I 843 in Epistolario, Iv, pp. 304-7; reprinted in Denis Mack Smith, ed., Il risorgimento italiano: storia e testi, pp. I I $3^{-1} 5$. 
would thus be to ignore the 'natural limits' of Italian culture, denying the nation the 'lustre' of its principal institution. ${ }^{31}$

The details of Gioberti's depiction of the role of the church through the centuries need not detain us unduly. He sought to identify the church, both as an institution and as a doctrinal fount, with flourishing periods in Italy's past. His reading of the medieval period, in particular, was very different from Mazzini's. Where Mazzini stressed the emergence of autonomous political life at local levels in the communes, Gioberti focused instead on the crucial role of the papacy. In the fierce controversies between empire and papacy, he sided unambiguously with the latter. Whatever common life Italy enjoyed in the centuries following the collapse of Rome derived from the church's imposition of patterns of conduct and shared beliefs. Though it had become fashionable through the influence of Machiavelli, Sarpi, and Dante to portray the church as an obstacle to national unity, the fact remained that the church alone had saved a culture from the threat of disintegration and established a viable foundation for further development. The Ghibellines, far from easing the thraldom endured by Italian society at the hands of the church, had actually introduced an extraneous element which rendered the identity of the society precarious. Pagan principles of organization, coupled with a nominalist philosophy that emphasized the subjective character of belief and experience, reinforced precisely the centrifugal tendencies which the church had always sought to counter. In the end, the church would be unable to secure its position, suffering a doctrinal catastrophe in the Reformation which had far-reaching implications for the nation as a whole. An event that had been welcomed by so many in the name of freedom only served to deepen Italy's dependence upon foreign powers, undermining her special spiritual status without releasing native talents and initiatives. Italy could progress in the future only through recognition of her original source of strength. The Guelphs in earlier centuries had championed a papal politics and a realist philosophy. And though much had changed in the aftermath of the French Revolution, the need for an objective civil and religious framework remained.

'The Guelph idea is in itself just and sacred; and I regard it as the only reasonable solution to the intricate and much canvassed problem of Italian national identity. Philosophically it is the application of realism to the civil institutions of Italy; historically it is the only idea which is a fitting reflection of the original genius of the nation and of its special conditions after the establishment of Christianity; practically it is the only idea which can be adopted without error and delirium. ${ }^{32}$

But Gioberti was not simply arguing that the church, as a distinctive national institution, should necessarily be taken into account in any political plans for the future. Religion was crucial to any society, moulding attitudes and dispositions and facilitating mutual understandings. In Italy's case, however, the church's supranational position distinguished her as 'the religious nation par excellence'. ${ }^{33}$ Before the fragmentation of the respublica christiana Italy's pre-

$$
{ }^{31} \text { Ibid., p. 8o. } \quad{ }^{32} \text { Ibid., p. } 77 . \quad{ }^{33} \text { Ibid., p. } 3^{2 .}
$$


eminence had been unchallenged. Rome, as the spiritual heart of Christian Europe, could exercise an influence which bore no relation to the economic or military power at her disposal. Not only could she function as a moral and religious arbiter; but her original role in the imposition of a specifically Christian civilization had enabled her to dominate in political, legal and administrative spheres long before the various states of Europe had assumed a settled form.

Nor was Italian pre-eminence restricted to religion. Gioberti saw culture in its broadest sense, embracing both the organized body of the arts and sciences and the unspoken assumptions which inform judgements in daily life, as an emanation from a specifically religious vision. And because religion could be well or ill conceived, straying more or less from the truth, it followed that the value of a cultural edifice would depend upon the viability of its foundations. Since Gioberti equated Catholicism with the truth and Italy with Catholicism, he automatically set Italy at the head of the nations. Her religious autonomy made her an initiator where other nations were the receivers of the benefits of civilization. ${ }^{34}$ While in speculative fields ranging from philosophy, through mathematics and the physical sciences, to history, the fine arts, and literature, her sound dogmatic base secured her an unrivalled position. ${ }^{35}$

Much had changed, of course, with the Reformation. The integrity of the Catholic world had been sullied by the proliferation of heretical sects. And the apparent economic and political decline of Italy relative to France, England, and Prussia made it the more difficult to identify Italian culture with all that was best in the arts and sciences. Yet Europe as a whole, following the traumas of revolution and reaction, could by no means be said to be either tranquil or flourishing. French dominance had been associated with the dislocation and expropriation of local economies. While Austria would not long be able to sustain her defence of outmoded principles of organization and control. The new world of emerging nations called for a different style of political leadership. And Gioberti was convinced that Italy was perfectly placed to reclaim her earlier prerogatives. Her religion still cast her as the 'autonomous and authoritative nation par excellence'; and because she had first given 'the seeds of civilization to the cultured nations of the modern world', she could resume her position because her original principles remained intact. ${ }^{36}$ Despite the disappointments and humiliations of the last 300 years, Italian culture remained essentially sound. If she could grasp her opportunity, not only would she set her own political house in order but European leadership would beckon once more.

Gioberti had sought to build his case around two quite separate considerations. The first concerned the identification of the church as a central pillar of Italian national consciousness, crucial to the conception Italians formed of themselves but also involved in all aspects of lay adminstration; the

\footnotetext{
${ }^{34}$ See ibid., pp. 53-6o.

${ }^{35}$ Gioberti develops his detailed case for Italian primacy in the arts and sciences at length in ibid., II, passim.

${ }^{36}$ Ibid., vol. I, p. 59
} 
second, more speculatively, asserted that religion provided the creative inspiration for all civilizations. Running the arguments together, Gioberti could advance audacious claims for Italy's past and future roles which could satisfy both the pride of the church and the ambitions of secular nationalists. With deceptive ease he could argue that since 'the religious primacy of Italy is ... undoubted, and because religion by its nature occupies the highest standing in human affairs', it followed that religion should 'confer upon the Italians a dominant moral and civil position'. ${ }^{37}$ Whatever the merit of Gioberti's theoretical justification, there can be no doubting the rhetorical force of his stratagem. He had exploited the thrust of anti-rationalist arguments without endorsing the reactionary views which had been associated with such positions since I 8 I 5 . He hoped thereby that the suspicions and fears of groups which had linked the reform movement with hostility to religion and tradition might have been allayed, whilst at the same time nationalists would be encouraged to broaden the basis of their appeal.

\section{I I}

The argument from religious primacy could only advance Gioberti's political case so far. It would not, in itself, resolve sensitive questions about the kind of political formation appropriate to Italian conditions, nor the sorts of tactics which nationalists might best adopt. Many radicals, indeed, Mazzini included, viewed the prospect of a resurgent papacy with some alarm, fearing the extension of the blend of cultural despotism and inefficient administration that had so signally marked the Papal States in recent years. At the very least, however, Gioberti could claim that Italy's distinctive religious tradition made it inappropriate for her to seek political models beyond her own culture. Cultural autonomy implied political autonomy. Gioberti makes the point emphatically: 'Italy contains within herself, principally through religion, all the requisite conditions for her national and political Risorgimento. ${ }^{38} \mathrm{It}$ followed that whatever strategies she adopted to advance her political cause should respect her principal cultural asset and particular identity, ruling out both 'internal revolutions' and liberation by foreign arms. ${ }^{39}$

Options for the future thus depended upon the configuration of forces within a variegated national culture. A principle of unity had to be sought; but it had to be 'real, concrete, alive and solidly rooted' in the culture, 'not abstract and in the air, because states govern themselves neither with chimeras nor abstractions'. ${ }^{40}$ Gioberti's objection to the unitarists was precisely that their views did 'not emanate from a conception of the country, nor correspond to particular Italian conditions, nor have a national foundation'; they were rather 'castles in the air' fashioned 'in imitation of foreign doctrines and examples'. ${ }^{41}$

Gioberti was not claiming that a unitary state was everywhere and always

37 Ibid., p. 8I.

${ }^{38}$ Ibid., p. I 26.

39 Ibid., p. I 26.

40 Ibid., p. I 27. 
inappropriate. He admitted, indeed, that in pure theory it had a pleasing, even 'beautiful' aspect. ${ }^{42}$ What he could not allow, however, was that the merits of particular forms of state should be considered in disregard of circumstances. He insists that a 'civil system is without practical value unless it is adapted to the particular conditions of the time and place in which it is to be applied '. ${ }^{43}$ Italy's centuries old divisions would simply not admit of rapid reduction to a single centre of power without chronic dislocation which would undermine established rights and interests. And since 'in politics a timely and applicable good should be held to be the best', it followed that Italians should pursue a polycentric system which would better reflect the imprint of their history. ${ }^{44}$

The federal idea was not new to Italy. Gioberti traces its roots to the early Etruscan confederations, finding recurring echoes in Pythagorean schemes of hierarchical association, the Italic league and the Lombard leagues. Each of the federal experiments, in fact, 'having to be essentially both a totality and a multiplicity', required 'a unitary principle' which would not 'annul the variety' of its constituent parts. ${ }^{45}$ In Italy such a principled focus had always been available through religion and the clergy, where rule would be exercised 'not through force of arms but through wisdom and conscience', allowing the various states and local centres to perform appropriate functions throughout the peninsula. ${ }^{46}$ The idea of a papal-led Italian confederacy had been implicit in the medieval period, especially under Gregory VII, without being specifically associated with the national principle. The shifting priorities of post-Napoleonic Europe, however, had made the fate of nations the urgent political question of the day. By linking federalism, Catholicism, and nationalism, Gioberti had exploited principal currents in Italian history, urging a political innovation which could be said to be rooted in culture and tradition.

The political form favoured by Gioberti was a self-conscious resurrection of an original Guelph idea. Where the medieval papacy had sought to mobilize an alliance of like-minded cities against the imperial ambitions of the Ghibellines, Gioberti argued for a confederation of the established Italian states, with the pope as symbolic figure-head, as a means towards the liberation of Italy from foreign control and influence. ${ }^{47}$ It was an idea that had long been mooted in the country, 'perfectly fitted to the nature, customs, institutions and geographical conditions of the peninsula' ${ }^{48}$ Most important of all, it was the simplest of schemes to put into practice. It could be adopted by the several states with the least disturbance to their domestic arrangements, while holding out the prospect of longer-term political, economic, and cultural improvements which would be of benefit to all.

Gioberti is suggestive, but brief, in his treatment of detailed institutional measures. He refers to federalism in a generic sense throughout the text but insists that a more limited confederal framework is more appropriate to Italy. The basic distinction between federalism and confederalism is drawn from
42 Ibid., p. I 4 I.
43 Ibid., p. I4 I.
44 Ibid., p. I4I.
45 Ibid., p. I 43.
46 Ibid., p. I 43.
47 See ibid., pp. I $45^{-6 .}$
48 Ibid., p. I 42 . 
Henry Wheaton's Elements of international law ( 1836$).{ }^{49}$ Wheaton uses the term confederalism to describe a system in which 'the several states are connected together by a compact which does not essentially differ from an ordinary treaty of equal alliance', leaving 'the sovereignty of each member of the union... unimpaired '. ${ }^{50}$ In this scheme of things, 'the resolutions of the federal body' are 'enforced, not as laws directly binding on the private individual subjects but through the agency of each separate government, adopting them, and giving them the force of law within its own jurisdiction'. ${ }^{51}$ In the case of federalism, however,

the federal government created by the act of union is sovereign and supreme within the sphere of the power granted to it by that act, and the sovereignty of each several state is impaired both by the powers thus granted to the federal government, and the limitations thus imposed on the several states' governments. ${ }^{52}$

Gioberti is clear that his own proposal, guaranteeing as it did the sovereignty and independence of each constituent state, should, in Wheaton's terms, be classed as confederal.

On the specific division of institutional functions Gioberti offers no more than hints. But he does light upon a principle which has assumed growing significance in the recent history of federal theory. Jurisdictional disputes between central and local authorities have always bedevilled the functioning of federal systems, rendering the theoretical designation of clear areas of competence all but impossible. Gioberti's solution is deceptively simple. In what might be taken to be an anticipation of the modern doctrine of subsidiarity, he argues that 'the secret of hierarchical harmony lies in the central power not expanding beyond spheres of common concern which regard the state as a whole, while the particular affairs of its constituent parts be left by the federative power in the hands of those directly involved ${ }^{53}$ In the case of Italy, where the central power would depend principally upon 'moral authority', the 'ancient rights of each Italian sovereign regarding the internal ordering of his state would be fully preserved', leaving 'affairs of common interest' to be handled by an 'assembly of the various princes'. ${ }^{54}$

Nor did Gioberti restrict his point to the peculiar functioning of federal systems. In what is a clear allusion to the measure of administrative decentralization which Mazzini incorporated in his own theory of the state, Gioberti claimed that 'the concept of federation has a place in the theory of the centralisti, though imperfectly and excessively subordinated to the predominant unitary power; otherwise, instead of a government, one would have an intolerable, even impossible, tyranny'. ${ }^{55}$ The contention, then, is that all legitimate government must take into account in one fashion or another the variety of local needs and circumstances. Federalism was distinctive precisely because it elevated practical necessity to the status of an essential tenet of

\footnotetext{
49 Henry Wheaton, Elements of international law (2 vols., London, I 836).

50 Gioberti, Del primato morale e civile degli italiani, I, p. 482.

52 Ibid., p. 482. $\quad 53$ Ibid., p. I 49. $\quad{ }^{54}$ Ibid., pp. I49-50. 55 Ibid., p. I47.
} 
theory, making federal government 'the best adapted to the pattern and natural course of human society'. ${ }^{56}$

Gioberti's analysis of the general advantages of a federal state is rather more conventional. He sees the pooled strength of the Italian states as a safeguard against both 'domestic upheavals, wars and revolutions' and 'foreign invasions'. ${ }^{57}$ Effective control of her own confines would restore Italy to 'the first rank among the powers', enabling her to make a significant contribution to the organization of Europe as a whole. ${ }^{58}$ She could also make an impact upon the wider world by resuming imperial expeditions, setting herself on the same international footing as the other major powers.

On the domestic front, the abolition of differences in 'weights, measures, currencies, customs duties and language which miserably and narrowly divide the various provinces and impede in a thousand ways the intellectual and commercial dealings of the several members of the nation' would signally advance the economic, cultural, and social development of the nation, gradually eroding 'municipal divisions and rivalries'. ${ }^{59}$ Mutual security, too, would be reinforced through 'reciprocal agreements', ensuring that the 'extinction of the line of any prince' would not be the occasion for a recurrence of 'barbarian invasions' and 'execrable wars of succession'. ${ }^{60}$

The prospect of enhanced security, indeed, was held out by Gioberti as a principal incentive for established governments to flock to the confederal standard. He saw his own age as a period of transition in which irresistible pressures for change were building up. To refuse to alleviate at least some of that pressure was to court problems in the future which might well prove to be disastrous. The real lesson of the French revolutionary period, for Gioberti, was that intransigent conservatism was as utopian as the dreams of the revolutionaries. The ancien régime had crumbled and, despite efforts to turn the clock back after I 8 I5, a settled civil form had yet to emerge in Europe. Ordinary people, however, had little interest in grandiose ideological schemes. What they sought was a modest but tangible amelioration in their civil affairs, with a reasonable assurance that further improvements would be forthcoming. They had been driven into the arms of the revolutionaries only because "every other means of obtaining civil reforms' had been blocked. ${ }^{61}$ If rulers wanted to secure their thrones, they thus had little alternative but to embrace the cause of reform. In this perspective, Gioberti's confederal scheme had obvious appeal. He promised a major national reform which would nevertheless involve minimal institutional disruption in the several Italian states. More important still, future reform could be managed by mutual agreement of established governments, ensuring that civil reform did not degenerate into political revolution.

Gioberti was aware, of course, that the creation of a confederal Italian state was much more than a narrowly domestic affair. An Italian nation-state of whatever kind could only emerge at Austrian expense; while the collapse of Austrian interests in Italy was likely to trigger a series of nationalist uprisings

\footnotetext{
56 Ibid., p. I 46.

57 Ibid., p. I 39.

58 Ibid., p. I 39.

59 Ibid., pp. $\mathrm{I}_{40} \mathrm{O}^{-} \mathrm{I}$.

60 Ibid., p. I4I.

61 Ibid., p. 2 I I.
} 
elsewhere in the empire which might prove difficult to contain. Clearly Austria had a great deal to lose in Italy both economically and politically. There could be little doubt that she would defend her position with all the resources at her disposal, including her formidable army. Gioberti nowhere explains precisely how a papal-led confederacy could be expected to handle the diplomatic implications of a war of liberation against a Catholic power. But he is aware that military resources would have to come from somewhere. He envisages a special role for Piedmont ('la provincia guerriera'), with her proud military traditions. ${ }^{62}$ And, indeed, his confederacy of equal partners begins to look on closer inspection like an axis built around Rome and Piedmont, the former 'the privileged seat of Christian wisdom', the latter 'the principal base of Italian military strength ${ }^{9}{ }^{63}$ Between the cultural hegemony of the church and the military hegemony of Piedmont, other constituent states would probably find little room for manoeuvre. But this, again, was an issue which Gioberti was reluctant to press. He avoids discussion of the best means of striking a balance between constitutional prerogatives and de facto power, largely in order to make the prospect of an Italian confederation as attractive as possible to the powers most likely to make it a success.

What principally emerges from a tangled text is the range of interests which Gioberti had managed to accommodate. Established governments would have little to fear from a confederal state, at least in the short term, and a great deal to gain in terms of security. The church, arguably the leading 'national' institution, would find itself once again occupying not only a central political role nationally but also internationally. Piedmont could expect to secure a dominant voice in the formulation of foreign policy, while at the same time restraining the more ambitious schemes for domestic reform in the other constituent states. Reformers, too, could see the creation of a national state as a new beginning, advancing by degrees the sorts of piecemeal improvements which had previously been blocked by foreign, municipal, and regional interests. Only revolutionaries and reactionaries were excluded from the feast Gioberti had prepared.

It may be that in seeking to maximize the political appeal of his text, Gioberti had compromised unduly on certain crucial theoretical issues. The vexed question of popular involvement, for example, which liberals tended to welcome in theory but to avoid in practice, is barely mooted in the text. But Gioberti is not alone among the liberals of his generation in evading this issue. Like Mill and de Tocqueville, he feared the political impact of the untutored masses. He never doubted, however, the educative role of a political life conducted through regular institutions. In terms of preparation for politics, there could be no substitute for practical engagement; but engagement had to stem from gradual involvement which would not undermine the confidence of established interests. In time, a 'democratic' liberalism might be conceivable; without appropriate experience, however, such a venture would be the height

$$
{ }^{62} \text { Ibid., p. I65. } \quad{ }^{63} \text { Ibid., p. I77. }
$$


of folly. In a real sense, the cause of progress had more to fear from its passionate advocates than its reactionary opponents.

\section{V}

Gioberti also felt the need almost immediately to clarify his position with regard to the Jesuits. ${ }^{64}$ And certainly his own experience of the frustrations and disappointments of government in the heady atmosphere of I $848 \mathrm{led}$ him to modify his views on both the appropriate form for an Italian state and the best means of achieving it. ${ }^{65}$ But it was the Primato which had the decisive impact upon political debate, providing a theoretical focus for a wide range of cautious but forward-looking groups and interests. Italian moderates in the i 840 os may not have constituted a political party in the narrow sense but they now enjoyed a collective identity which dramatically enhanced their capacity to initiate policy and respond to developments.

It should not be supposed, however, that the moderates endorsed the detail of Gioberti's Primato. What his most discerning readers focused upon was not so much the role of the papacy as that of Piedmont. Cesare Balbo ( I 789-I 853), for example, whose Catholic orthodoxy was never questioned, saw Piedmontese military strength as the crucial factor in the Italian situation. While he could accept the broad thrust of Gioberti's defence of the role of Catholicism in the development of Italian and European civilization, he could not envisage significant political initiatives emanating from the papacy. Gioberti, it should be stressed, privately accepted Balbo's reservations. In a letter of i 8 August I 843 he acknowledged that 'temporal government' in the Papal States is 'the worst and most disordered' in Italy. ${ }^{66}$ But he felt that to admit as much openly would undermine any prospect there might be of converting the church to the national cause. Balbo, on the other hand, discounted papal leadership from the outset. He was addressing the same liberal Catholic audience as Gioberti but with a firmer grasp of the limitations of both the Papal States as currently constituted and the wider international context.

Balbo's Delle speranze d'Italia ( I 844) must be seen, like Gioberti's Primato, as a self-conscious attempt to detach the national movement from Mazzinians and sectarians. ${ }^{67}$ Balbo acknowledged that his own work would have been inconceivable without the impetus of the Primato. In a letter to Gioberti he describes the Primato as 'a great book, ... a major event in the history of Italian literature and politics'. ${ }^{68}$ Delle speranze d'Italia was, in fact, dedicated to Gioberti and broke new ground principally on tactical and strategic questions. Balbo was clear that Austrian domination of Lombardy and Venice should be terminated. He recognized, however, that Austrian presence in Italy was an

\footnotetext{
${ }^{64}$ See Vincenzo Gioberti, Prolegomeni del Primato morale e civile degli italiani (Lugano, I 846); and Vincenzo Gioberti, Il gesuita moderno (5 vols., Lausanne, I846-7).

65 See Vincenzo Gioberti, Il Rinnovamento civile d'Italia, ed. Pier Angelo Menzio (Florence, i 925).

${ }^{66}$ Gioberti, Epistolario, Iv, p. 3 I о.

${ }^{67}$ Cesare Balbo, Delle speranze d'Italia, ed. Achille Corbelli (Turin, I948).

68 See Candeloro, Storia dell'Italia moderna, II, p. 386.
} 
intrinsic dimension of the wider European balance of power. He rejected the idea of an anti-Austrian confederation led by the papacy but shared Gioberti's fear of popular insurrections. It was unlikely that the other Italian states would find Piedmontese domination acceptable; nor was Piedmontese military capacity sufficient to fashion a united Italy without help from abroad. Fundamental political change in Italy, in Balbo's view, would require a radical readjustment of the European balance of power. His hope was that Austria might be persuaded to accept losses in Italy in return for a strengthening of her position in the Balkans. Fundamental changes in the Balkans were, in Balbo's view, inevitable, no matter what might happen in Italy. The Ottoman empire was in long-term decline. The crucial question was simply how the political vacuum might be filled. The European powers faced a stark choice between Austrian or Russian domination of an area which had always been unstable. Concerted European support for Austria seemed to Balbo to be the best means of advancing the Italian cause, without running the risk of widespread popular unrest. ${ }^{69}$ He certainly did not see the emergence of a nation-state in Italy as the first in a series of national revolutions which would effectively undermine the Austrian empire. Nor did he link national revolution in Italy with a major challenge to the position of established elites.

Balbo's detailed proposals need not detain us here. What is significant in the context of this study, however, is the terms in which he defended a confederal Italian state. He accepts the polycentric nature of Italian political culture as an inescapable historical burden. It is simply the case that the great cities (he cites Turin, Milan, Florence, Rome, Naples, Parma, and Modena, omitting, somewhat surprisingly, Venice) are loci of political power. ${ }^{70}$ Any suggestion that the citizens of such cities would willingly accept subordination by one among them he regards as dangerously utopian; and subordination by force would simply inflame entrenched antagonisms. To dream of a single capital for a unitary state was thus both foolish and naive, running counter not only to Italian history but to the general consensus in Europe that excessive centralization was harmful to provincial interests.

Balbo thus endorsed Gioberti's contention that 'confederations are the political form best adapted to the nature and history of Italy' ${ }^{71} \mathrm{He}$ took it as self-evident that the cultures of northern and southern Italy, like the cultures of northern and southern Europe, were so different that they would necessarily require separate administrations to suit their various circumstances. The example of the twelfth-century Lombard league had shown how independence could be defended through confederation. The resurrection of the idea by Gioberti, in the context of the delicate state of political debate within Italy, constituted an event of national rather than simply literary or historical significance. $^{72}$

What Gioberti and Balbo had exploited was the deep suspicion that all moderates shared of expressions of discontent from the lower classes. Insur-

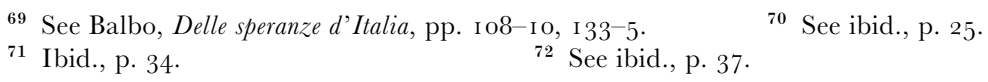


rections which depended upon fomenting popular unrest were intrinsically unstable. They ran the risk of sparking off a concatenation of uprisings which could elicit an authoritarian response from both domestic and international authorities. The moderates had recognized, as Mazzini had not, that political change in Italy could not be isolated from wider international considerations. The princes of Italy might be persuaded to pursue a concerted campaign against Austria. If the principal impetus for change were seen to come from Mazzinians and other revolutionary sectarians, the more probable outcome was that the princes would themselves seek the assistance of Austria in defence of the status quo.

Federalism or confederalism thus figured in moderate thinking as a lowest common political denominator rather than as a principle. Gioberti and Balbo had given the idea political credibility. Thenceforth it could be invoked without being argued for, at least until the major reassessment of strategy provoked by the failure of the 1848 revolutions. Even where the specific neoGuelph reading of Italian history was rejected, the political implication was left suspended.

The real novelty in moderate political discourse in the middle years of the I 84 os is the urgency of tone. A seemingly unbridgeable gulf had emerged between revolutionaries and sectarians on the one side and various species of (often theologically buttressed) reactionary and absolutist on the other. Left to itself, the situation showed every sign of degenerating. A revolutionary cataclysm on the scale of I 789 could not be discounted. Upheaval on that scale would threaten the limited political progress made in Italy and Europe. The moderates as a group were aware that they could be swamped. It thus behoved them to maximize the impact of the very considerable political advantages they currently enjoyed. Gioberti and Balbo had provided them with the outlines of an historically informed political theory and strategy. What they now needed was a programme. 